\title{
Identifying a Cut-off Point for Timed Up and Go Test in Neuromuscular Diseases
}

\author{
Nöromusküler Hastalıklarda Zamanlı Kalk ve Yürü Testinin Kesme Noktasının \\ Belirlenmesi
}

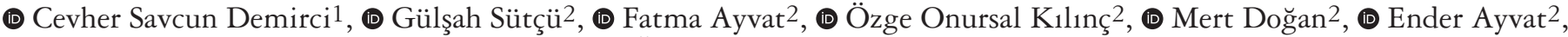

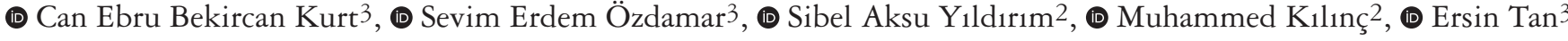

${ }_{1}^{1}$ Balikesir University Faculty of Health Sciences, Department of Physiotherapy and Rehabilitation, Balikesir, Turkey

2Hacettepe University Faculty of Physical Therapy and Rehabilitation, Ankara, Turkey

3Hacettepe University Faculty of Medicine, Department of Neurology, Ankara, Turkey

\begin{abstract}
Objective: Balance problems and falls due to a progressive loss of muscle strength in neuromuscular diseases (NMD) negatively affect the activities of daily living and functional independence of patients. The timed up and go (TUG) test is an easy-to-apply and objective measure of balance. This study aimed to determine the cut-off value of the TUG test in adult individuals with NMD.

Materials and Methods: This retrospective study included 102 patients. The receiver operating characteristic analysis was performed and cut-off, sensitivity, and specificity values were calculated in NMD to determine the diagnostic validity of the TUG test.

Results: The mean ages of 55 patients with a fall history and 47 patients without a fall history were $34.40 \pm 10.41$ and $31.87 \pm 10.11$ years, respectively. The mean values of the TUG scores of these individuals were calculated as $11.79 \pm 4.30$ and $7.33 \pm 1.51 \mathrm{~s}$, respectively. The cut-off value of the TUG test in adult individuals with the NMD was determined as $8.9 \mathrm{~s}$.

Conclusion: The present study revealed that individuals with NMD who complete the TUG test over $8.9 \mathrm{~s}$ have a high risk of falling. Determining the risk of falling in NMD, which is one of the neurological patient groups where falling complaints are most common, is extremely important for patient safety and the effectiveness of rehabilitation.
\end{abstract}

Keywords: Neuromuscular diseases, TUG, cut-off value, falling

Öz

Amaç: Nöromusküler hastalıklarda (NMH) ilerleyici kas kuvvet kaybına bağlı olarak denge problemleri ve düşmeler, hastaların günlük yaşam aktivitelerini ve fonksiyonel bağımsızlı̆̆ını olumsuz bir şekilde etkilemektedir. Zamanlı kalk ve yürü testi (ZKYT), uygulaması kolay ve objektif bir denge değerlendirmesidir. Bu çalışmanın amacı, NMH olan yetişkin bireylerde ZKYT testinin kesme değerini belirlemektir.

Gereç ve Yöntem: Retrospektif çalışmaya 102 katılımcı dahil edildi. ZKYT testinin diagnostik geçerliliğini belirlemek için alıcı işlem karakteristikleri analizi yapılarak NMH'de kesme, duyarlılık ve özgüllük de ğerleri hesaplandı.

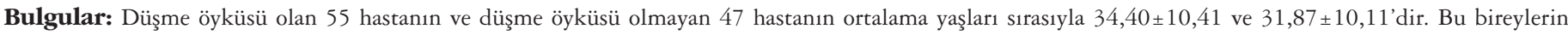
ZKYT puanlarının ortalama de ğerleri sırasıyla $11,79 \pm 4,30$ ve 7,33 $\pm 1,51$ saniye olarak hesaplanmıştır. NMH olan yetişkin bireylerde ZKYT testinin kesme değeri 8,9 saniye olarak belirlendi.

Sonuç: Mevcut çalışmanın sonuçları, ZKYT testini 8,9 saniyenin üzerinde tamamlayan NMH olan bireylerin düşme riskinin yüksek olduğunu göstermektedir. Düşme şikayetlerinin en sık görüldüğü nörolojik hasta gruplarından biri olan NMH'de düşme riskinin belirlenmesi hastaların güvenliği ve rehabilitasyonun etkinliği açısından son derece önemlidir.

Anahtar Kelimeler: Nöromusküler hastalıklar, ZKYT, kesme değeri, düşme

Address for Correspondence/Yazışma Adresi: Cevher Savcun Demirci, PT, Balikesir University Faculty of Health Sciences, Department of Physiotherapy and Rehabilitation, Balikesir, Turkey Phone: +90 2662440010 E-mail: cevhersavcun@hotmail.com ORCID: orcid.org/0000-0002-8786-7496

Received/Geliş Tarihi: 27.04.2021 Accepted/Kabul Tarihi: 03.12.2021

${ }^{\circ}$ Copyright 2022 by Turkish Neurological Society

Turkish Journal of Neurology published by Galenos Publishing House. 


\section{Introduction}

Neuromuscular diseases (NMD) constitute a heterogeneous disease group that is acquired or is genetically characterized by progressive muscular atrophy and weakness. The primary finding includes loss in muscle strength, joint movement restrictions, progressing disease age, muscle shortness, contractures and deformities, decreased respiratory capacity, posture disorders, pain, walking difficulty, balance disorder, and falls. The progressive findings that accompany the disease cause difficulties in mobility and transfers in patients, falling, activity difficulties in climbing stairs and standing up from the ground, and activity of daily living (ADL) limitations (1). Falls can develop because of intrinsic factors (e.g., age, disease duration, degree of loss of muscle strength, and body mass index, etc.), or extrinsic factors (e.g., environmental factors, such as lack of lighting and non-complying sidewalks and stairs). The only study conducted in the NMD group on this topic revealed that 49 of 80 patients $(61.25 \%)$ were reported to have fallen at least twice in the last 6 months, and these patients could be called fallers. Additionally, the study reported that $94 \%$ of patients fell outside their homes, whereas $74 \%$ experienced fear of falling (2).

Falling and fear of falling are not the primary findings in patients with diseased muscle; however, predicting the outcomes of falling (i.e., fractures, immobilization, head traumas, etc.) and taking the necessary precautions is important (3). Therefore, the evaluation of falling and fear of falling in this patient group is an important step in the quality of life and ADL participation.

The timed up and go (TUG) test is a fast, easy-to-apply, and objective measurement tool for functional balance (4). It is frequently used as a valid measurement of mobility and balance especially in the elderly but is also widely used in many groups of neuromuscular $(5,6)$, neurological $(7,8)$, and pediatric $(9,10)$ patients. The test, which is also considered a strong indicator of functional mobility (11), was shown to be successful in distinguishing falling and not falling in individuals with low functional levels (12), with high test and re-test and interintrarater reliability $(8,13,14)$.

NMD evaluation and accurate result analyses obtained in this way are very important for the success of rehabilitation. These patients must especially be analyzed well because the disease is progressive, as well a look for some important findings that may arise in the rehabilitation process. After all, limitations affect the success of rehabilitation. The literature review revealed the cut-off value of studies for the TUG test in different groups $(11,15,16)$. Determining the cut-off value is an important datum for predicting and distinguishing the patient who has the risk of falling. The TUG test is frequently used in the patient group who has history of frequent falling and fear of falling; however, the cut-off value is unavailable. Thus, this study aimed to determine the cut-off value of the TUG test in adult individuals with NMD.

\section{Materials and Methods}

\section{Study Design and Population}

A retrospective study was carried out on patients with muscle disease who applied to Faculty of Physical Therapy and Rehabilitation, Hacettepe University between 2017 and 2020. The approval was received from Hacettepe University Non-
Interventional Clinical Research Ethics Committee (approval no: 2020/20-98, date: 2020/20).

Inclusion criteria were (i) ages of $18-65$ years, (ii) muscular disease diagnosis by a neurologist, and (iii) the ability to walk without support or walking aid.

Exclusion criteria were (i) any other neurological or orthopedic diseases, (ii) history of fracture, connective tissue and muscle injury, and joint problems that may affect the lower extremity, and (iii) cognitive problems or cooperation difficulties.

\section{Assessments}

\section{Demographic Data and Clinical Characteristics}

The demographics of patients, such as age, gender, height, and weight, were obtained from the patient assessment forms.

\section{Timed Up and Go Test}

In the TUG test, individuals stand up from a chair, walk $3 \mathrm{~m}$, turn around, walk back to the chair, and sit down (4). The starting position was standardized, with the patients' feet flat on the floor and their arms resting on the armrests. The individual is asked to complete the test at their own pace and as quickly as possible. The test was initiated with the command "start" and ended with the individual sitting on the chair again. The test was performed three times. Rest breaks of 2 min were given between each trial. During the tests, the clinician timed the performance for each trial with a chronometer and recorded it.

\section{Statistical Analysis}

The Statistical Package for the Social Sciences version 21 (SPSS Inc., Chicago, IL, USA) was used for statistical analysis. The conformity of variables to normal distribution was examined by visual (histogram and probability graphics) and analytical methods (Kolmogorov-Smirnov or Shapiro-Wilk tests). The MannWhitney $U$ test was used to analyze group differences between patients with and without a fall history. The capacity of TUG test values in predicting falls was analyzed using the receiver operating characteristic (ROC) curve analysis. The highest combination of sensitivity and specificity was taken to determine the optimal cutoff (significant limit) value.

\section{Results}

\section{Participants}

This study included 102 individuals with NMD, consisting of 22 females and 33 males in the faller group and 16 females and 31 males in the non-faller group. Patients consisted of 21 with limb-girdle muscular dystrophy, 13 with Becker muscular dystrophy, 3 with fasioscapulohumeral muscular dystrophy, 19 with myotonic dystrophy, 12 with other muscular dystrophies, and 34 with other myopathies. The mean ages of patients were $34.40 \pm 10.41$ and $31.87 \pm 10.11$ in the faller and non-faller groups, respectively. The demographics and the TUG test scores of patients are shown in Table 1.

The demographic and clinical score examination of both groups revealed a statistically significant difference in illness duration and TUG scores between the faller and non-faller groups. Additionally, the effect size analyses determined a large effect of falling on TUG test scores and a small effect in illness duration on TUG test scores. (Table 1). 
Table 1. Demographic characteristics and TUG test scores of participants

\begin{tabular}{|c|c|c|c|c|}
\hline & \multicolumn{4}{|c|}{ Group statistics } \\
\hline Demographics & $\begin{array}{l}\text { Faller } \\
(n=55) \\
X \pm S D\end{array}$ & $\begin{array}{l}\text { Non-faller } \\
(n=47) \\
X \pm S D\end{array}$ & $\mathrm{p}$ & $\begin{array}{l}\text { Standardized } \\
\text { effect size } \\
\text { Cohen's D }\end{array}$ \\
\hline Age (years) & $34.40 \pm 10.41$ & $31.87 \pm 10.11$ & 0.213 & 0.24 \\
\hline Height $(\mathrm{cm})$ & $168.12 \pm 9.93$ & $169.23 \pm 7.83$ & 0.545 & 0.12 \\
\hline Weight (kg) & $67.34 \pm 13.39$ & $66.62 \pm 13.94$ & 0.539 & 0.05 \\
\hline Duration of illness (day) & $102.40 \pm 69.05$ & $74.68 \pm 76.47$ & $0.008^{*}$ & 0.38 \\
\hline TUG (sec) & $11.79 \pm 4.30$ & $7.33 \pm 1.51$ & $<0.001^{*}$ & 1.38 \\
\hline
\end{tabular}

${ }^{*} \mathrm{p}<0.05$ (Mann-Whitney U test), BMI: Body mass index, TUG: Timed up and go test, X: Mean, SD: Standard deviation

The ROC analysis determined an $8.92 \mathrm{~s}$ clinical cut-off point for TUG in individuals with NMD. Scores that equal to $8.92 \mathrm{~s}$ or less, with $95 \%$ confidence, was considered as normal for TUG in NMD (95\% confidence interval lower bound: 0.827, upper bound: 0.947 ; area under the curve: 0.887 ; standard deviation error: $0.031 ; \mathrm{p}<0.001$ ) (Figure 1 ). The sensitivity and specificity of the TUG test are shown in Table 2.

\section{Discussion}

Our study results, revealed a precise TUG test measurement to determine the risk of falling in NMD, indicating that patients who complete the test over $8.9 \mathrm{~s}$ have a high risk of falling. Therefore, the TUG test, which is an easy and practical functional mobility test, can be used in determining the risk of falling in NMD.

The TUG test is a practical evaluation tool that is frequently used in clinics and studies. TUG performance was shown to reflect mobility level (17), predict a disability development in ADL $(18,19)$, and succeed in separating individuals with and without falls (13). The TUG test is a comprehensive evaluation of balance, muscle strength, and agility and gives a quick idea of both the functionality of the patient in the ADL and the development in the rehabilitation process by evaluating the functions, such as standing up from a chair, walking, turning, and sitting again onto the chair. Additionally, the TUG test quickly evaluates the main problems, such as loss of muscle strength and balance, which result from biomechanical changes in NMD.

Studies conducted in older adults regarding the TUG test in the literature revealed that many studies were conducted to determine the cut-off value. These studies determined different cut-off values, such as $7.7 \mathrm{~s}(20), 12 \mathrm{~s}$ in fragile adults over 50 years of age (21), and $13.5 \mathrm{~s}$ in older women between the ages of 65 and 85 living in the society (13). Studies are mostly conducted in older adults; however, many studies were reported in the neurological and NMD group in which the TUG test was used for functional evaluation $(22,23,24,25)$ with its validity and reliability in some NMD groups $(9,26)$. The study of Dunaway et al. (6) revealed that the TUG test and re-test reliability in patients with spinal muscular atrophy was high and was associated with total leg and knee flexor strength, Hammersmith functional motor scale, and 10 meter and 6 minute walking tests. Montes et al. (5) emphasized after the 6-month measurements in patients with amyotrophic lateral sclerosis (ALS) that TUG performance linearly decreased,

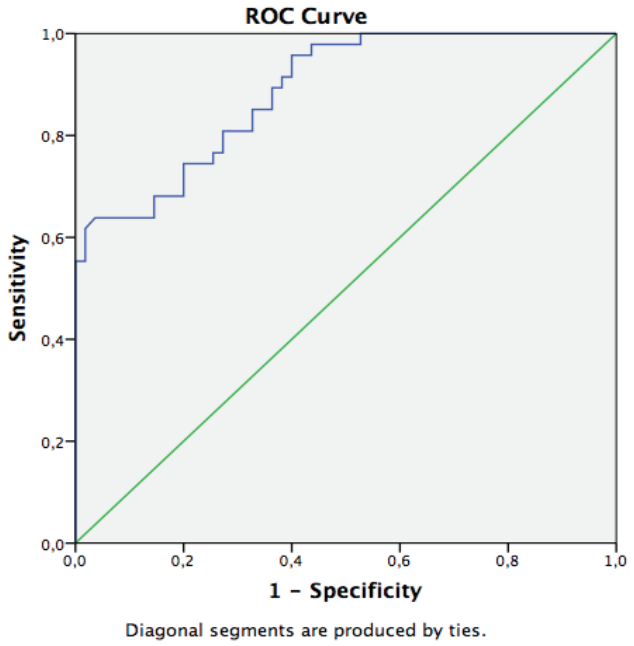

Figure 1. ROC-curve for TUG test. The discriminant power of TUG is determined as high

ROC: Receiver operating characteristic, TUG: Timed up and go test

$\begin{array}{llllll}\text { Table } & \text { 2. The sensitivity and specificity of TUG test } \\ \text { Tests } & \begin{array}{l}\text { AUC } \\ \text { (SEM) }\end{array} & \begin{array}{l}\text { 95\% } \\ \text { CI }\end{array} & \begin{array}{l}\text { Cut-off } \\ \text { point }\end{array} & \begin{array}{l}\text { Sensitivity } \\ (\%)\end{array} & \begin{array}{l}\text { Specificity } \\ (\%)\end{array} \\ \text { TUG } & 0.887 & \begin{array}{l}0.827- \\ 0.947\end{array} & 8.92 & 80.9 & 72.7\end{array}$

TUG: Timed up and go test, AUC: Area under the curve, CI: Confidence interval, SEM: Standard error of measurement

ALS functional evaluation scale and manual muscle test evaluations were correlated, those who completed the test at $14 \mathrm{~s}$ had a $10 \%$ risk of falling, and this limit could be used for walking assistant recommendation. Hammarén et al. (26) found that the test and retest reliability of the TUG test was high in patients with myotonic dystrophy type 1 , and evaluating the balance performance of patients during walking was recommended.

The TUG test is a commonly used assessment tool in the myopathy group; however, no cut-off value was determined for this group of patients in the literature. Hammarén et al. (27) evaluated 72 patients with myotonic dystrophy type 1 and 220 healthy participants, determined the reference value for TUG in the healthy group, and showed a statistically significant difference 
by comparing the mean TUG value of the patient group with this value. The reference value given by Hammarén et al. (27) for the healthy group was $7.6 \mathrm{~s}$, and the mean TUG value for the myotonic dystrophy group was $10.4 \mathrm{~s}$. Additionally, according to the muscular impairment rating scale, which was developed to evaluate the process of muscle involvement in myotonic dystrophy type 1 , they found the value as $8.6 \mathrm{~s}$ in the mild group and 11.4 $\mathrm{s}$ in the severe group when they divided the participants into two groups. Our study revealed the cut-off value as $8.9 \mathrm{~s}$ in the TUG test for adult individuals with NMD with a history of falling. Patients who spend time above this value to complete the test are believed to be at risk of falling. Additionally, the difference between disease durations between the two groups, the higher falling rates of those who were fighting this disease, and the significantly higher duration of completing the TUG test support Hammarén et al.'s (27) results, and show that falls may increase and balance may deteriorate as disease duration and severity increase in the NMD group.

\section{Study Limitations}

The limitation of this study includes the absence of classification according to the disease severity or functionality of the evaluated patients. Furthermore, the study was conducted in a heterogeneous group of patients who had different NMD types. Separation of the groups that will be analyzed in future studies according to disease severity or functional level and determining the cut-off value by evaluating each disease individually can provide more understandable and interpretable results in studies and clinical practice.

\section{Conclusion}

The TUG test can help identify patients who are at risk of falling as a clinical screening test that is used widely in adult individuals with NMD. Our study results are important because it is the first study to determine a cut-off value in this patient group based on the history of falling.

\section{Ethics}

Ethics Committee Approval: The approval was received from Hacettepe University Non-Interventional Clinical Research Ethics Committee (approval no: 2020/20-98, date: 2020/20).

Informed Consent: Informed consent was obtained from all participants included in the study. The files of the patients who allowed the use of their data were reviewed retrospectively.

Peer-review: Internally peer-reviewed.

\section{Authorship Contributions}

Concept: C.S.D., C.E.B.K., S.E.Ö., S.A.Y., M.K., E.T., Design: C.S.D., C.E.B.K., S.E.Ö., S.A.Y., M.K., E.T., Data Collection or Processing: G.S., F.A., Ö.O.K., M.D., E.A., Analysis or Interpretation: C.S.D., M.D., E.A., Literature Search: G.S., F.A., Ö.O.K., M.K., Writing: C.S.D., G.S., M.K.

Conflict of Interest: No conflict of interest was declared by the authors.

Financial Disclosure: The authors declared that this study received no financial support.

\section{References}

1. Mary P, Servais L, Vialle R. Neuromuscular diseases: Diagnosis and management. Orthop Traumatol Surg Res 2018(Suppl 1);104:89-95.

2. İyigün G, Yildirim SA, Atay S, Kilinc M, Tan E. Factors negatively affecting falling in patients with neuromuscular diseases: a prospective study. Turk J Physiother Rehabil 2008;19:97-103.
3. Pieterse A, Luttikhold T, de Laat $\mathrm{K}$, et al. Falls in patients with neuromuscular disorders. J Neurol Sci 2006;251:87-90.

4. Podsiadlo D, Richardson S. The timed "up \& go": a test of basic functional mobility for frail elderly persons. J Am Geriatr Soc 1991;39:142-148.

5. Montes J, Cheng B, Diamond B, et al. The timed up and go test: predicting falls in ALS. Amyotroph Lateral Scler 2007;8:292-295.

6. Dunaway S, Montes J, Garber CE, et al. Performance of the timed "up \& go" test in spinal muscular atrophy. Muscle Nerve 2014;50:273-277.

7. Ries JD, Echternach JL, Nof L, Gagnon Blodgett M. Test-retest reliability and minimal detectable change scores for the timed "up \& go" test, the sixminute walk test, and gait speed in people with Alzheimer disease. Phys Ther 2009;89:569-579.

8. Morris S, Morris ME, Iansek R. Reliability of measurements obtained with the timed "up \& go" test in people with Parkinson disease. Phys Ther 2001;81:810-818.

9. Aras B, Aras O, Karaduman A. Reliability of balance tests in children with Duchenne muscular dystrophy. Sci Res Essays 2011;6:4428-4431.

10. Dhote SN, Khatri PA, Ganvir SS. Reliability of "modified timed up and go" test in children with cerebral palsy. J Pediatr Neurosci 2012;7:96-100.

11. Bohannon RW. Reference values for the timed up and go test: a descriptive meta-analysis. J Geriatr Phys Ther 2006;29:64-68.

12. Schoene D, Wu SMS, Mikolaizak AS, et al. Discriminative ability and predictive validity of the timed Up and Go test in identifying older people who fall: systematic review and meta-analysis. J Am Geriatr Soc 2013;61:202208.

13. Shumway-Cook A, Brauer S, Woollacott M. Predicting the probability for falls in community-dwelling older adults using the timed up \& go test. Phys Ther 2000;80:896-903.

14. Steffen TM, Hacker TA, Mollinger L. Age-and gender-related test performance in community-dwelling elderly people: six-minute walk test, Berg balance scale, timed up \& go test, and gait speeds. Phys Ther 2002;82:128-137.

15. Huisinga J, Bruetsch A, Mccalley A, et al. An instrumented timed up and go in facioscapulohumeral muscular dystrophy. Muscle Nerve 2018;57:503-506.

16. Decavel P, Moulin T, Sagawa Y Jr. Gait tests in multiple sclerosis: reliability and cut-off values. Gait Posture 2019;67:37-42.

17. van Iersel MB, Munneke M, Esselink RA, Benraad CE, Olde Rikkert MGO Gait velocity and the timed-up-and-go test were sensitive to changes in mobility in frail elderly patients. J Clin Epidemiol 2008;61:186-191.

18. Donoghue OA, Savva GM, Cronin H, Kenny RA, Horgan NF. Using timed up and go and usual gait speed to predict incident disability in daily activities among community-dwelling adults aged 65 and older. Arch Phys Med Rehabil 2014;95:1954-1961.

19. Makizako H, Shimada H, Doi T, et al. Predictive cutoff values of the five-times sit-to-stand test and the timed "up \& go" test for disability incidence in older people dwelling in the community. Phys Ther 2017;97:417-424.

20. Tang PF, Yang HJ, Peng YC, Chen HY. Motor dual-task timed up \& go test better identifies prefrailty individuals than single-task timed up \& go test. Geriatr Gerontol Int 2015;15:204-210.

21. Bischoff HA, Stähelin HB, Monsch AU, et al. Identifying a cut-off point for normal mobility: a comparison of the timed 'up and go'test in communitydwelling and institutionalised elderly women. Age Ageing 2003;32:315-320.

22. Eichinger $\mathrm{K}$, Heatwole $\mathrm{C}$, Iyadurai $\mathrm{S}$, et al. Facioscapulohumeral muscular dystrophy functional composite outcome measure. Muscle Nerve.2018;58:72-78.

23. Filli L, Schwegler S, Meyer C, et al. Characterizing cognitive-motor impairments in patients with myotonic dystrophy type 1. Neuromuscul Disord 2020;30:510-520.

24. Caronni A, Picardi M, Aristidou E, et al. How do patients improve their timed up and go test? Responsiveness to rehabilitation of the TUG test in elderly neurological patients. Gait Posture 2019;70:33-38.

25. Leavy B, Joseph C, Löfgren N, et al. Outcome evaluation of highly challenging balance training for people with Parkinson disease: a multicenter effectivenessimplementation study. J Neurol Phys Ther 2020;44:15-22.

26. Hammarén E, Ohlsson JA, Lindberg C, Kjellby-Wendt G. Reliability of static and dynamic balance tests in subjects with myotonic dystrophy type 1 . Adv Physiother 2012;14:48-54.

27. Hammarén E, Kjellby-Wendt G, Kowalski J, Lindberg C. Factors of importance for dynamic balance impairment and frequency of falls in individuals with myotonic dystrophy type 1-A cross-sectional study-including reference values of timed up \& go, 10m walk and step test. Neuromuscul Disord 2014;24:207-215. 